\title{
Histamine contents in raw long-ripening meat products commercially available in Poland
}

\author{
Mirosław Michalski ${ }^{\bowtie}$, Marzena Pawul-Gruba, Anna Madejska \\ Department of Hygiene of Food of Animal Origin, \\ National Veterinary Research Institute, 24-100 Puławy, Poland \\ mmichal@piwet.pulawy.pl
}

Received: July 15, $2021 \quad$ Accepted: November 10, 2021

\begin{abstract}
Introduction: Many consumers seek long-ripening meat products. The availability of these highly distinctive cured pork varieties is continuously expanding and their safety should be subject to monitoring. One of potentially harmful substances in these products is histamine. The presence of this toxic amine is reported in many countries, even in high concentrations. However, the EU has not regulated the permissible histamine content in meat, in a situation at odds with that of regulated fish and fish products. This study established the usefulness of biogenic amine testing in long-ripening pork and furnished indicative concentrations potential useful as a background for future research in preparation for EU regulative intervention. Material and Methods: A total of 97 samples of long-ripening meat products untreated by heat were bought from various shops in the Puławy and Lublin regions of Poland and tested for the presence of histamine using high-performance liquid chromatography with diode array. Results: The histamine concentration ranged from below limit of detection to $346.64 \mathrm{mg} / \mathrm{kg}$, where $3.47 \mathrm{mg} / \mathrm{kg}$ was the lowest in a positive sample. Histamine was detected in 48 samples (49.5\%). The maximum amount of histamine was identified in dry ham and the minimum in traditional salami. Conclusion: The results of this study suggest that testing meat products for biogenic amines should be a very good indicator of the food safety of long-ripening meats. In half of the tested products, levels of biogenic amines potentially toxic to consumers were determined.
\end{abstract}

Keywords: histamine, high-performance liquid chromatography with diode array, long-ripening meat products, dry meat products.

\section{Introduction}

Traditional fermented dry and long-ripening meat products have been refined over centuries according to local traditions and artisanal practices and constitute an important component of the modern diet. Consumer concern for food safety and high demand for traditional food products are challenges for producers of these types of cured pork. Meeting demand may remain problematic because of the irreconcilability of accelerated production and long ripening. However, safety is afforded by successful meat fermentation, which is a two-stage process of fermentation and ripening resulting in the development of an environment inhibitory to most pathogens. This holds true for fermented dry sausages, where the hygiene status of the processing environment and equipment plays a pivotal role in their microbiological safety.

During recent years consumers have been looking for food at the highest biological safety levels. They have become more aware of positive and negative attributes and careful in analysing product labels for ingredients beneficial for health. The current trend of bringing the health positive characteristics of food to the fore gives impetus to the search for and elimination of compounds that may have a negative influence on human health. Nevertheless, safe residue limits for potentially harmful substances are currently defined only for a specific group of foods. This is the case for histamine, for which the limit is legislatively specified only for fish and processed fish (12). Little quantitative information is available concerning the histamine content of meat products such as fermented/ripening sausage and cured meat varieties which have the potential for it to develop. Dry sausages should contain only 1 to $2 \mathrm{mg} / \mathrm{kg}$ of histamine, which is the physiological muscle histamine level. When contaminated by undesirable microorganisms or the addition of starter bacteria, histamine concentrations in such meat may even exceed $100 \mathrm{mg} / \mathrm{kg}(14,36)$. 
Based on the chemical structure and number of amine groups of histamine (2-[4-imidazolyl] ethylamine), it is classified as a heterocyclic diamine. Important physiological activities of histamine in the human organism include synaptic transmission, blood pressure control, allergic response and cellular growth control $(20,29)$. It can cause intoxication and trigger intolerance symptoms. Histamine intoxication manifests itself in cardiovascular, respiratory, haematological, gastrointestinal and neurological symptoms such as headaches, palpitation, hypotension, urticaria and other rashes, oedema, oral burning, vomiting, diarrhoea, cramping, and swelling $(4,20,32)$. Consumption of products containing histamine at a toxic concentration can cause a serious allergic reaction and even forerun cancer of the digestive tract $(19,20,34)$. Histamine is degraded in the human body by oxidative deamination catalysed by monoamine and diamine oxidases $(4,18$, $27,37)$. The lighter symptoms after intoxication usually resolve within $24 \mathrm{~h}(18,20,30)$. However, after ingestion of food with high concentrations of histamine, in the absence or low abundance of these enzymes (e.g. due to genetic factors, allergy, or ingested alcohol), the detoxification system is unable to eliminate histamine sufficiently, and in some individual cases hospitalisation is necessary $(4,6,17)$.

Histamine can be formed by bacteria naturally present in a large variety of types of food, particularly in fish, cheeses, wines, beer, and all other fermented drinks, and ripened meat products $(7,9,23,32,35)$. It is a product of the decarboxylation of histidine in a one pathway reaction, catalysed by the bacterial enzyme, decarboxylase (26). The most common bacterial species responsible for histamine production in different types of fermented food (cheese, dry-fermented cured meat and wine) are Morganella morganii, Photobacterium psychrotolerans, Photobacterium phosphoreum, Klebsiella pneumoniae, Lactobacillus spp., Oenococcus oeni, Pediococcus parvulus, Pediococcus damnosus, Enterobacter aerogenes, Enterobacter cloacae, Escherichia coli, Hafnia alvei, Klebsiella oxytoca, Serratia liquefaciens, Tetragenococcus spp. and Leuconostoc spp. The involvement of Enterobacteriaceae in the production of histamine can be particularly deep $(13,16,18,24,25)$. Besides the naturally present bacteria, there are also many exogenous microorganisms responsible for decarboxylation reactions which may be introduced as starter cultures into some types of meat products $(2,3)$.

Histamine production in different meat products can be influenced by many factors, e.g. the types of bacterial starter culture and endogenous bacterial presence, unintended bacterial contamination during the production process, $\mathrm{pH}$, salt concentration, nitrate or nitrite food additives, storage temperature and ripening time $(2,26)$. The long time and high temperature of ripening of meat products are among the histamine poisoning in humans (19).
The provisions of the European Union regulations specify a permissible level of histamine only for fish and fish products $(12,34)$. Currently, there are no officially established criteria for the level of this amine in meat products. In fact, no biogenic amine has a permissible level set by any country for meat and meat products, including long-ripening ones. An amount of 500 to $1,000 \mathrm{mg} / \mathrm{kg}$ of histamine in a food product is a potential threat to human health, and addressing this danger, some countries have recommended an upper limit for histamine residue, such as the Netherlands where a $100-200 \mathrm{mg} / \mathrm{kg}$ maximum was proposed (18).

The objective of this study was to determine the concentration of histamine in raw long-ripening meat products for human consumption in Poland in 2018-2019 using high performance liquid chromatography with diode array detection (HPLC-DAD).

\section{Material and Methods}

A total of 97 samples of raw long-ripening meat products from various local shops and supermarkets in the Puławy and Lublin regions of Poland were tested for the presence of histamine. The samples were purchased from available cured pork products in stores, taking into account the long-ripening varieties selected at the experimental design stage. The investigation covered thirteen available assortments and a geographical origin diversity of Poland, France, Germany, Spain and Hungary. After purchasing, the samples were immediately delivered to the laboratory and processed. The sampled products were within their shelf-lives. Some varieties were in one piece, and some were sliced, and the latter were vacuum-packed or packaged in a modified atmosphere. Before preparing the samples for analysis, the casings were removed as necessary.

Histamine content was determined by HPLC-DAD, according to our validated procedures. A meat product sample of $10 \pm 0.01 \mathrm{~g}$ was weighed into a $50 \mathrm{~mL}$ polypropylene centrifuge tube. Twenty-five millilitres of $0.2 \mathrm{M}$ trichloroacetic acid was added and the sample was mixed for $1 \mathrm{~min}$, centrifuged for $10 \mathrm{~min}$ at $4,000 \times \mathrm{g}$ at $15^{\circ} \mathrm{C}$ and kept at $\leq 18^{\circ} \mathrm{C}$ for $30 \mathrm{~min}$. The upper lipid layer coating was discarded. Five millilitres of the supernatant was then transferred into a $10 \mathrm{~mL}$ Erlenmeyer flask which was filled with water. The sample was cleaned up with a solid phase extraction (SPE) apparatus (J.T. Baker, Deventer, the Netherlands) and polymeric weak anion SPE cartridges $200 \mathrm{mg}, 3 \mathrm{~mL}$ (Phenomenex, Torrance, CA, USA). The cartridges were conditioned with $5 \mathrm{~mL}$ of methanol followed by $10 \mathrm{~mL}$ of phosphate buffer $(0.01 \mathrm{M}, \mathrm{pH} 3.0)$. Seven millilitres of the extract was transferred to an SPE column and passed through the cartridge into a $10 \mathrm{~mL}$ Erlenmeyer flask. Next, the SPE column was washed with $2 \mathrm{~mL}$ of phosphate buffer and filtered extract was supplemented to $10 \mathrm{~mL}$ with phosphate buffer. 
Table 1. Histamine contents in long-ripening meat products

\begin{tabular}{|c|c|c|c|c|c|}
\hline \multirow{2}{*}{ Assortment } & \multicolumn{2}{|c|}{ Number of samples } & \multirow{2}{*}{$\begin{array}{l}\text { Range for positive } \\
\text { samples, }(\mathrm{mg} / \mathrm{kg})\end{array}$} & \multirow{2}{*}{$\begin{array}{c}\text { Mean } \pm \text { SD } \\
(\mathrm{mg} / \mathrm{kg})\end{array}$} & \multirow{2}{*}{$\begin{array}{c}\text { Percentage of positive } \\
\text { samples, }(\%)\end{array}$} \\
\hline & Tested & Positive & & & \\
\hline Air-dried salami & 6 & 2 & $3.99 ; 7.01$ & na & 33.3 \\
\hline Black Forest ham & 4 & 1 & 30.98 & na & 25.0 \\
\hline Dry ham (Jamón, Serrano, Dulano) & 11 & 9 & $30.08-346.64$ & $131.88 \pm 118.65$ & 81.8 \\
\hline Kindziukas & 13 & 11 & $21.02-110.54$ & $41.78 \pm 27.76$ & 84.6 \\
\hline Polish ripening ham & 3 & 0 & na & na & na \\
\hline Provençal ham & 5 & 2 & $74.00 ; 165.01$ & na & 40.0 \\
\hline Ripening bacon & 4 & 0 & na & na & na \\
\hline Ripening gammon & 2 & 2 & $14.40 ; 71.50$ & nd & 100.0 \\
\hline Ripening Parma ham & 15 & 12 & $11.00-292.61$ & $97.07 \pm 82.83$ & 80.0 \\
\hline Ripening porkloin & 3 & 0 & na & na & na \\
\hline Salami (Milano, Toscano) & 7 & 4 & $18.61-121.5$ & $33.04 \pm 48.52$ & 57.1 \\
\hline Slightly dried pork loin & 1 & 1 & 210,00 & na & 100.0 \\
\hline Traditional salami & 23 & 4 & $3.47-30.06$ & $14.63 \pm 12.67$ & 17.4 \\
\hline Total & 97 & 48 & $3.47-346.64$ & $76.64 \pm 81.88$ & 49.5 \\
\hline
\end{tabular}

na-not applicable

The instrumental analysis was performed using Varian ProStar HPLC apparatus (Agilent Technologies, Santa Clara, CA, USA) equipped with quaternary pump, autosampler, column thermostat and diode array detector, controlled by Galaxie Workstation software (Agilent Technologies). Separation was conducted on Unisol C18 columns of $150 \times 4.6 \mathrm{~mm}, 3 \mu \mathrm{m}$ with precolumns of $10 \times 3 \mathrm{~mm}, 3 \mu \mathrm{m}$ (Agela Technologies, Torrance, CA, USA). The mobile phase consisted of methanol and $0.1 \mathrm{M}$ potassium dihydrogen phosphate with $1.6 \mathrm{mM}$ 1-octanesulphonic acid (150:850,v:v) and was applied under isocratic conditions. The column oven temperature was maintained at $25^{\circ} \mathrm{C}$ and a flow rate of $0.5 \mathrm{~mL} / \mathrm{min}$ was used. The injection volume was $20 \mu \mathrm{L}$. Ultraviolet detection was monitored at $215 \mathrm{~nm}$. The range of the method was $3.28-420 \mathrm{mg} / \mathrm{kg}$, whereas the limits of detection (LOD) and quantification were $2.76 \mathrm{mg} / \mathrm{kg}$ and $3.28 \mathrm{mg} / \mathrm{kg}$, respectively (34).

\section{Results}

The results of analysis of histamine in longripening meat products without heat treatment are shown in Table 1.

In the present study, the histamine concentration determined by HPLC-DAD ranged from below the LOD to $346.64 \mathrm{mg} / \mathrm{kg}$. Histamine was detected in 48 samples (49.5\%): air-dried salami (two samples), Black Forest ham (one sample), dry ham (nine samples), kindziukas (eleven samples), Provençal ham (two samples), ripening gammon (two samples), Parma ham (twelve samples), Milano salami (four samples), slightly dried pork loin (one sample) and traditional salami (four samples). In three examined products, (Polish ripening ham, ripening bacon and ripening porkloin) histamine was not detected in ten samples. The concentration of histamine in positive samples was between 3.47 and $346.64 \mathrm{mg} / \mathrm{kg}$, the minimum amount of histamine being found in green pepper salami (Konecke), and the maximum amount in dry ham, Jamón Serrano Reserva from Spain.

\section{Discussion}

Histamine is one of the most important and toxic biogenic amines in a wide range of foods, including in the important elements of our diet which meat and meat products are $(5,7,14,38)$. It is produced during the bacterial decarboxylation of the histidine present in different food products. Any food that contains the appropriate amino acids and is contaminated certain growing bacteria may poison the ingester with histamine. It is all the more dangerous because neither cooking, canning, nor freezing reduces its toxic effect. On the contrary, cooking, grilling, and frying increase histamine levels in meat products $(11,38)$. Refrigeration practice is one of the most important factors in impeding histamine formation in food because it prevents bacterial spoilage if it is diligent. However, in the case of ripening meat products, the temperatures of production and storage are higher and allow bacteria to grow. High temperatures of approximately $25-30^{\circ} \mathrm{C}$ have been described by many authors as optimal for most histaminogenic microorganisms $(11,28)$. In meat products, many factors such as $\mathrm{pH}$, formulation (e.g. animal species, salting or nitrites), starter cultures, technological conservation processes, high hydrostatic pressures, irradiation and packaging (vacuum or modified atmosphere) interplay to determine if and by how much histamine becomes more concentrated 
$(10,21,31)$. The main rise histamine level probably occurs during the first two weeks of ripening and can be slowed down if $\mathrm{pH}$ can be lowered during fermentation processes, particularly if a starter culture of bacteria was used $(8,36)$.

In a survey conducted in Finland by Eerola et al. (14), it was reported that 68 retail samples of different slowly fermented dry sausageswhich were tested for histamine included some which contained this amine in the range of $<1-200 \mathrm{mg} / \mathrm{kg}$. In Turkey, in 19 samples of traditional fermented sausages (Sucuk), histamine was found at levels from $9.21 \mathrm{mg} / \mathrm{kg}$ up to $362 \mathrm{mg} / \mathrm{kg}$. Only one sample was free of histamine (5). Also in Turkey, 120 sausage samples contained histamine in a range from 0 to $469.37 \mathrm{mg} / \mathrm{kg}$ (15). Fifty-eight samples of dry fermented salami and dry ripened meat products were analysed in 2008 in Greece for histamine presence. The maximum level of histamine was $514 \mathrm{mg} / \mathrm{kg}$ and $28 \%$ of the analysed products contained the amine in excess of the limit of $100 \mathrm{mg} / \mathrm{kg}$ mandated for fish $(12,33)$. Besides being revealed in sausages, histamine was also detected in other fermented or aged meat products. It occurred in home-made ham in the range of $0.82-2.66 \mathrm{mg} / \mathrm{kg}$, in salami in the range of $0.74-7.81 \mathrm{mg} / \mathrm{kg}$ and in semi-dry sausage in the range of $1.80-7.47 \mathrm{mg} / \mathrm{kg}$ (33).

Poultry meat production and consumption have increased rapidly worldwide and consumption will continue to grow and be a source of food poisoning by histamine in many regions. Histamine was detected in fresh chicken meat stored either aerobically or under modified atmosphere packing conditions from the eleventh day of storage and after two weeks its level had reached $26.8 \mathrm{mg} / \mathrm{kg}$ (5). This amine was also found in raw poultry thigh $(10.88 \pm 0.91$, maximum $22.4 \mathrm{mg} / \mathrm{kg})$ and raw breast $(8.17 \pm 0.53$, maximum $15.5 \mathrm{mg} / \mathrm{kg})(22)$. Silva and Glória (37) also confirmed the presence of histamine in fresh poultry meat at the level of $10.3 \mathrm{mg} / \mathrm{kg}$. This means that fresh meat also can be a source of histamine intoxication for consumers, especially given that thermal processes are known not to eliminate histamine (11). In fresh meat products (those not ripened), histamine was detected in the range of $0.63-1.41 \mathrm{mg} / \mathrm{kg}(1)$. The occurrence of the high level of histamine in ripening meat products may be a significant sign of problems in raw materials and/or production process conditions (temperature, humidity and hygiene).

The results of this study suggest that testing meat products for biogenic amines, especially histamine, should be a very good indicator of their quality, freshness, and safety for consumers. Although in many tested meat products histamine was found at various levels, most of them were below acceptable levels according to EU regulations pertaining to fish. The relevance of these levels is that in food law only for fish and fish products does a limit exist (12). However, the extremely high levels of histamine of 346.64 or $292.61 \mathrm{mg} / \mathrm{kg}$ are very disturbing from a health point of view. It is therefore justified to consider monitoring the content of histamine in meat products, especially those longripening, and to establish a maximum limit.

Conflict of Interests Statement: The authors declare that there is no conflict of interests regarding the publication of this article.

Financial Disclosure Statement: This study was supported by the Polish Ministry of Science and Higher Education within the statutory activity of the National Veterinary Research Institute.

Animal Rights Statement: None required.

\section{References}

1. Algahtani F.D., Morshdy A.E., Hussein M.A., Abouelkheir E.S., Adeboye A., Valentine A., Elabbasy M.T.: Biogenic amines and aflatoxins in some imported meat products: Incidence, occurrence, and public health impacts. J Food Qual 2020, 8718179, doi: 10.1155/2020/8718179.

2. Alvarez M.A., Moreno-Arribas M.V.: The problem of biogenic amines in fermented food and the use of potential biogenic aminedegrading microorganisms as a solution. Trends Food Sci Technol 2014, 39, 146-155, doi: 10.1016/j.tifs.2014.07.007.

3. Ansorena D., Montel M.C., Rokka M., Talon R., Eerola S., Rizzo A., Raemaekers M., Demeyer D.: Analysis of biogenic amines in northern and southern European sausages and role in amine production. Meat Sci 2002, 61, 141-147, doi: 10.1016/S0309-1740(01)00174-7.

4. Attaran R.R., Probst F.: Histamine fish poisoning: a common but frequently undiagnosed condition. Emerg Med J 2002, 19, 474-475, doi: 10.1136/emj.19.5.474

5. Balamatsia C.C., Paleologos E.K., Kontominas M.G., Savvaidis I.N.: Correlation between microbial flora, sensory changes and biogenic amines formation in fresh chicken meat stored aerobically or under modified atmosphere packaging at $4{ }^{\circ} \mathrm{C}$ : possible role of biogenic amines as spoilage indicators. Antonie van Leeuwenhoek 2006, 89, 9-17, doi: 10.1007/s10482-0059003-4.

6. Bodmer S., Imark C., Kneubühl M.: Biogenic amines in foods:. Histamine and food processing. Inflamm Res 1999, 48, 296-300, doi: 10.1007/s000110050463.

7. Bonczar G., Filipczak-Fiutak M., Pluta-Kubica A., Duda I.: Biogenic amines present in cheese - occurrence and threats (in Polish). Med Weter 2017, 73, 136-143, doi: 10.21521/mw.5657.

8. Bunčić S., Paunović L., Teodorović V., Radišić D., Vojinović G., Smiljanić D., Baltić M.: Effects of gluconodeltalactone and Lactobacillus plantarum on the production of histamine and tyramine on fermented sausages. Int J Food Microbiol 1993, 17, 303-309, doi: 10.1016/0168-1605(93)90200-z.

9. Calzada J., del Olmo A., Picón A., Gaya P., Nuñez M.: Reducing biogenic-amine-producing bacteria, decarboxylase activity, and biogenic amines in raw milk cheese by high-pressure treatments. Appl Environ Microbiol 2013, 79, 1277-1283, doi: 10.1128/AEM.03368-12.

10. Chong C.Y., Abu Bakar F., Abdul Rahman R., Bakar J., Mahyudin N.A.: The effects of food processing on biogenic amines formation. Int Food Res J 2011, 18, 867-876.

11. Chung B.Y., Park S.Y., Byun Y.S, Son J.H., Choi Y.W., Cho Y.S., Kim H.O., Park C.W.: Effect of different cooking methods on histamine levels in selected foods. Ann Dermatol 2017, 29, 706-714, doi: 10.5021/ad.2017.29.6.706.

12. Commission of the European Communities: Commission Regulation (EC) No. 2073/2005 of 15 November 2005 on microbiological criteria for foodstuffs (Text with EEA relevance) OJ L 338, 22/12/2005, 1 . 
13. Durulu-Özkaya F., Ayhan K., Vural N.: Biogenic amines produced by Enterobacteriaceae isolated from meat products. Meat Sci 2001, 58, 163-166, doi: 10.1016/s0309-1740(00)00144-3.

14. Eerola H.S., Roig Sagués A.X., Hirvi T.K.: Biogenic Amines in Finnish dry sausages. J Food Saf 2007, 18, 127-138, doi: 10.1111/j.1745-4565.1998.tb00208.x.

15. Ekici K., Omer A.K.: The determination of some biogenic amines in Turkish fermented sausages consumed in Van. Toxicol Rep 2018, 5, 639-643, doi: 10.1016/j.toxrep.2018.05.008.

16. Emborg J., Dalgaard P.: Formation of histamine smd biogenic amines in cold-smoked tuna: an investigation of psychrotolerant bacteria from samples implicated in cases of histamine fish poisoning. J Food Prot 2006, 69, 897-906, doi: 10.4315/0362028X-69.4.897.

17. Ercan S.Ş., Bozkurt H., Soysal Ç.: Significance of biogenic amines in foods and their reduction methods. J Food Sci Eng 2013, 3, 395-410, doi: 10.17265/2159-5828/2013.08.001

18. European Food Safety Agency Panel on Biological Hazards (BIOHAZ): Scientific opinion on risk based control of biogenic amines formation in fermented foods. EFSA J 2011, 9, 2393, doi: 10.2903/j.efsa.2011.2393.

19. Feng Ch., Teuber S., Gershwin M.E.: Histamine (Scombroid) fish poisoning: a Comprehensive Review. Clinic Rev Allerg Immunol 2016, 50, 64-69, doi: 10.1007/s12016-015-8467-x.

20. Food and Agriculture Organization of the United Nations and World Health Organization: Joint FAO/WHO expert meeting on the public health risk of histamine and other biogenic amines from fish and fishery products, 23-27 July 2012, Food and Agriculture Organization of the United Nations, Rome, 2012, pp. 14-83.

21. Gardini F., Özogul Y., Suzzi G., Tabanelli G., Özogul F.: Technological factors affecting biogenic amine content in foods: A review. Front Microbiol 2016, 7, 1218, doi: 10.3389/fmicb.2016.01218.

22. Hemmat M.I., Amin R.A., Eleiwa N.Z., Ahmed N.M.: Estimation of some biogenic amines on chicken meat products. Benha Vet Med J 2017, 32, 23-28, doi: 10.21608/bvmj.2017.31108.

23. Hernández-Jover T., Izquierdo-Pulido M., Veciana-Nogués M.T., Mariné-Font A., Vidal-Carou M.C.: Biogenic amine and polyamine contents in meat and meat products. J Agric Food Chem 1997, 45, 2098-2102, doi: 10.1021/JF960790P.

24. Hungerford J.M.: Scombroid poisoning: A review. Toxicon 2010, 56, 231-243, doi: 10.1016/j.toxicon.2010.02.006

25. Kanki M., Yoda T., Ishibashi M., Tsukamoto T.: Photobacterium phosphoreum caused a histamine fish poisoning incident. Int J Food Microbiol 2004, 92, 79-87, doi: 10.1016/j.ijfoodmicro. 2003.08.019
26. Karowičová J., Kohajdová Z.: Biogenic amines in food. Chem Pap 2005, 59, 70-79.

27. Kovacova-Hanuskova E., Buday T., Gavliakova S., Plevkova J.: Histamine, histamine intoxication and intolerance. Allergol Immunopathol 2015, 43, 498-506, doi: 10.1016/j.aller. 2015.05.001

28. Latorre-Moratalla M.L., Bover-Cid S., Veciana-Nogués M.T., Vidal-Carou M.C.: Control of biogenic amines in fermented sausages: role of starter cultures. Front. Microbiol 2012, 3, 169, doi: 10.3389/fmicb.2012.00169.

29. Maintz L., Novak N.: Histamine and histamine intolerance. Am J Clin Nutr 2007, 85, 1185-1196, doi: 10.1093/ajcn/85.5.1185.

30. McLauchlin J., Little C.L., Grant K.A., Mithani V.: Scombrotoxic fish poisoning. J Public Health 2006, 28, 61-62, doi: 10.1093/pubmed/fdi063.

31. Naila A., Flint S., Fletcher G., Bremer P., Meerdink G.: Control of biogenic amines in food - existing and emerging approaches. J Food Sci 2010, 75, 139-150, doi: 10.1111/j.17503841.2010.01774.x.

32. Papageorgiou M., Lambropoulou D., Morrison C., Kłodzińska E., Namieśnik J., Płotka-Wasylka J.: Literature update of analytical methods for biogenic amines determination in food and beverages. Trends Anal Chem 2018, 98, 128-142, doi: 10.1016/ j.trac.2017.11.001.

33. Papavergou E.J., Savvaidis I.N., Ambrosiadis I.A.: Levels of biogenic amines in retail market fermented meat products. Food Chem 2012, 135, 2750-2755, doi: 10.1016/j.foodchem. 2012.07.049.

34. Pawul-Gruba M., Michalski M., Osek J.: Determination of histamine in fresh and smoked fish commercially available in Poland. Bull Vet Inst Pulawy 2014, 58, 301-304, doi: 10.2478/bvip-2014-0046.

35. Prester L.: Biogenic amines in fish, fish products and shellfish: A review. Food Addit Contam A 2011, 28, 1547-1560, doi: 10.1080/19440049.2011.600728.

36. Shalaby A.R.: Significance of biogenic amines to food safety and human health. Food Res Int 1996, 29, 675-690, doi: 10.1016/s0963-9969(96)00066-x.

37. Silva C.M.G., Glória M.B.A.: Bioactive amines in chicken breast and thigh after slaughter and during storage at $4 \pm 1{ }^{\circ} \mathrm{C}$ and in chicken-based meat products. Food Chem 2002, 78, 241-248, doi: 10.1016/s0308-8146(01)00404-6.

38. Suzzi G., Gardini F.: Biogenic amines in dry fermented sausages: a review. Int $\mathrm{J}$ Food Microbiol 2003, 88, 41-54, doi: 10.1016/s0168-1605(03)00080-1. 